\title{
A current approach to anticipation in sport / Un enfoque actual de la anticipación en el deporte
}

\author{
José-Antonio Navia $\mathbb{B}^{\mathrm{a}}$, Carlos Avilés $\mathbb{1}^{\mathrm{b}}$, Sergio López $\mathbb{1}^{\mathrm{c}}$, and Luis- \\ Miguel Ruiz (D) \\ ${ }^{a}$ Universidad Politécnica de Madrid; ${ }^{b}$ Universidad Complutense de Madrid; \\ ${ }^{c}$ Universidad Pontificia de Salamanca
}

(Received 11 April 2016; accepted 5 June 2016)

\begin{abstract}
The classical cognitive concept of anticipation and timing (for example, reaction time) somewhat limits the study of sports actions under spatio-temporal pressure. The presence, duration and evolution of the information of the opponents, spatio-temporal pressure, the evolution of the athlete's response movements or the degree of representativeness are some of the issues facilitating research into an anticipation that is better adjusted to the specific circumstances of interception tasks. This article proposes that temporalization of response actions is based on the balance between the spatio-temporal demands of the task, the athlete's action capabilities and the evolution of the reliability of the available variables. In order to obtain good performance in these actions under pressure, individual perceptual differences and possible interactions with other information sources must also be considered.
\end{abstract}

Keywords: temporalization; perception-action; performance; interception

Resumen: El concepto cognitivo clásico de anticipación y cronometría (por ejemplo, el tiempo de reacción) limita en cierto modo el estudio de las acciones deportivas bajo presión espaciotemporal. La presencia, duración y evolución de la información del oponente, la presión espaciotemporal, la evolución de los movimientos de respuesta del deportista o el grado de representatividad son algunos de los aspectos relevantes que permiten un estudio de la anticipación más ajustado a las circunstancias específicas de las tareas de interceptación. A lo largo del texto se propone que la temporalización de las acciones de respuesta se fundamentan en el equilibrio entre las demandas espaciotemporales de la tarea, las capacidades funcionales del deportista y la evolución de la fiabilidad de las variables disponibles. Para obtener buen rendimiento en estas acciones bajo presión, además hay que tener en cuenta las diferencias individuales perceptivas y las posibles interacciones con otras fuentes informativas.

English version: pp. 1-8 / Versión en español: pp. 9-16

References / Referencias: pp. 16-19

Translated from Spanish / Traducción del español: Liza D'Arcy

Authors' Address / Correspondencia con los autores: José-Antonio Navia, Facultad de CC de la Actividad Física y del Deporte (INEF), Universidad Politécnica de Madrid, Calle Martín Fierro, 7, Ciudad Universitaria, 28040 Madrid, España. E-mail: joseantonio.navia@upm.es 
Palabras clave: temporalización; percepción-acción; rendimiento; interceptación

The anticipation of athletes in tasks in which they must intercept or return highspeed balls has been one of the most studied issues in action-perception research in recent decades (e.g., Howarth, Walsh, \& Abernethy, 1984). The structure of certain tasks, such as the return of a tennis serve or football penalty, obliges the athlete to act on the border of the impossible, achieving perfectly timed actions with fine motor skill (competence).

Exploring which perceptual-motor processes underlie this expert performance has motivated researchers to analyse visual perception and the temporalization of movements. This stream of research converges in the now widely used term of anticipation, also known as visual anticipation (Williams, Davids, \& Williams, 1999, p. 97). In spite of its popularity and use in the literature, the concept of anticipation has generated certain controversy (e.g., Van der Kamp, Rivas, Van Doorn, \& Savelsbergh, 2008). This controversy has its origin in the theoretical root of the term, moves through the methodological designs of the studies and also includes the different terms and aspects related to it.

\section{Conceptualization of anticipation}

The terminology used to discuss the way of responding is fundamental for specialists in human movement (motor behaviour) given that the proper use of the different concepts and terms has a direct impact on the method used and the validity of different temporal measures. As Williams James emphasized in his classic Principles of Psychology, since the nineteenth century Reaction Time (RT) and mental timing have been one of the experimental paradigms most used in laboratories to measure the time it takes humans to react to a certain stimulus, thus facilitating the exploration of mental processes timings. For example, the classic study by Hick (1952) specified the main stimulus as the moment in which the filament of the bulb becomes incandescent. The participants' response was recorded when they pressed a morse key in front of them. In this way, the RT was measured as the time elapsed between the light turning on and when the participants pressed the morse key. Neuropsychological studies on neuronal delays (e.g., flash-lag effect; Nijhawan, 2002) suggest that this RT is the minimum time required by the nervous system to process such information (i.e., visual processing, multisensory integration, temporal encoding of information) and perform a simple action (production of the motor order). Although recent studies with athletes continue to use the RT paradigm, it is currently believed that this paradigm is not a reliable indicator of expert performance because it does not represent what actually happens in a sports context (e.g., Martínez de Quel, Bennett, Lopez-Adan, Zapico, \& Saucedo-Morales, 2015).

Sports actions are performed in the context of a competition and require complex moves or responses that have nothing to do with a simple action such 
as releasing a button, raising a hand or pressing a key. The use of terms such as response time (e.g., Avilés, Ruiz, Sanz, \& Navia, 2014; Triolet, Benguigui, Le Runigo, \& Williams, 2013), whole or part of the body movement, implement start time (e.g., Gillet, Leroy, Thouvarecq, Mégrot, \& Stein, 2010) and visuomotor delay (VMD; e.g., Bootsma, Fernandez, Morice, \& Montagne, 2010) seem to more clearly reflect the adaptations, adjustments, corrections or responses that athletes perform.

Specialists point to a distinction between RT and VMD in certain aspects (e.g., Carlton, 1992). RT is related to the cognitive information processing theory associated with discrete tasks, and averages approximately 180-200 ms (Vickers, 2007, p. 48). In contrast, VMD is associated with a direct and fast coupling between information and movement. VMD values can be very short (less than $100 \mathrm{~ms}$ ) when information is used online in rapid adjustments or adaptations during a relatively long movement (Bootsma et al., 2010, p. 1,059; Van der Kamp et al. Al., 2008, p. 124). Conversely, values of 200 and even $300 \mathrm{~ms}$ can also be obtained when the information is used in a discrete way at the beginning of the movement or in the case of a significant correction (Benguigui, Baurès, \& Le Runigo, 2008; Le Runigo, Benguigui, \& Bardy, 2010, p. 328). This great temporal variation is mentioned by some authors who, on the one hand, use the term visuomotor interval, which has a more neutral or flexible connotation as to the duration of the period of time between stimulus and movement, and on the other, criticize the traditional view in research that frequently interprets latencies as a minimum and invariable time (Caljouw, Van der Kamp, \& Savelsbergh, 2004; Michaels, Zeinstra, \& Oudejans, 2001).

The fundamental question that reflects the disparity in terminology and the values found is the lack of similarity between the laboratory and sports actions. Even the investigations related to VMD (a priori more representative) were carried out in controlled conditions (e.g., Benguigui et al., 2008). Sports actions are not so easily recorded, differentiating themselves from what happens in the laboratory in at least three aspects: (a) the relationship between stimulus and response; (b) the presentation of the stimulus; and (c) the registering of the response.

In regard to the first point, although the athlete who throws has initiative, there is still a mutual temporalization of the actions, a dependence on a relatively long course of action between the two opponents: the person who throws and the person who returns (Avilés, Benguigui, Beaudoin, \& Godard, 2002). For example, in the case of a football penalty, the goalkeeper, in order to try to save the ball, focuses on the penalty taker from the moment they place the ball in the penalty spot (Furley, Dicks, \& Memmert, 2012), becoming even more focused when the taker starts their approaching run-up to the ball (Dicks, Button, \& Davids, 2010b; Navia, Van der Kamp, \& Ruiz, 2013). Meanwhile, the taker also focuses on the goalkeeper, even sometimes modifying the direction of their kick based on the goalkeeper's actions (Noël, Furley, Van der Kamp, Dicks, \& Memmert, 2014).

This mutual dependence together with the relatively long duration of the event (e.g., the approach to the football penalty lasts between 1,000 and 
2,000 ms; Dicks et al., 2010b; Navia et al., 2013) means that determining the moment at which the stimuli or the response appear is not easy. As for the stimulus, there is consensus in the literature on interceptive anticipation to take the moment of contact between the thrower and the object as the reference for the temporal analysis of the sequence (Howarth et al., 1984). Not because the stimulus itself appears at that moment, but because it is when a crucial alteration occurs in the available optical information. Biomechanical studies confirm that the optical variables associated with movements before the throw may relate to some degree to the final direction of the object, but it is not until the hit and the first moments of the ball flight that the direction and velocity of the ball are totally correlated (e.g., Diaz, Fajen, \& Phillips, 2012). In other words, the athlete who is receiving does not perceive with certainty the direction and speed until the moment the ball is hit and its first moments of flight, which is why it seems reasonable to consider that instant as point 0 in chronometric analysis. For example, in the case of the football penalty, that moment corresponds to the contact between the kicker's foot and the ball (e.g., Savelsbergh, Williams, Van der Kamp, \& Ward, 2002), or in the case of tennis, the contact between the server's racket and the ball (Day, 1980). However, using that moment as a reference does not mean that the stimulus appears at that moment, since, as discussed, there is an availability of more or less reliable information in moments preceding that action.

Regarding the response, there is a disparity in criteria when registering the beginning of the interception movement. Some studies consider that the athlete who receives initiates their action when they move laterally towards either side (e.g., Farrow, Abernethy, \& Jackson, 2005). Others consider previous regulatory movements that occur before that lateral displacement (e.g., Avilés, Ruiz, Sanz, \& Navia, 2014). And to confuse the situation even more, other studies use the measurement of various variables (e.g., movements in the centre of gravity, start of the lateral displacement of the racket, etc.) as a temporal register of the response action (e.g., Gillet et al., 2010).

Finally, if one considers the three aspects mentioned above, the study holds that the athlete anticipates if the response register (usually the lateral displacement) occurs before the ball is hit, or contrary to that, reacts if they move after contact (e.g., Williams et al., 1999). Conversely, as we previously saw, there is a latency between the stimulus and response (RT around $180 \mathrm{~ms}$ or VMD over $100 \mathrm{~ms}$ ), so another interpretation would involve considering anticipation when the athlete moves below one of those time limits. For example, Triolet et al. (2013, p. 825) consider that if the tennis player begins their action before $160 \mathrm{~ms}$ after hitting the ball, they are anticipating, and if they do so after that time, they are reacting.

In sum, we see how both the moment of the response action and the quantification of anticipation itself could be reformulated from a theoretical and methodological perspective when considering whether it makes sense to establish a barrier between anticipation and reaction when it is a continuous process of temporalization and regulation of the movement of athletes. 


\section{Anticipating and calibrating the response}

The classic concept of visual anticipation refers to the expert athlete's ability to detect their opponent's body cues early and to predict the direction of the ball's delivery (Poulton, 1957). Following this cognitive trend, other authors have defined anticipation as the ability to correctly predict situations before they occur (e.g., Tenenbaum, Sar-El, \& Bar-Eli, 2000, p. 119). That is, from that perspective, anticipating would mean predicting correctly (e.g., written response) and not necessarily moving (cf. Van der Kamp et al., 2008). This predictive ability of anticipation stems from other specific cognitive abilities such as early recognition, pattern recognition, refined visual search or the use of situational probabilities (Williams \& Ford, 2008).

The temporal occlusion technique has been prolifically employed to register the spatial anticipation level of athletes (Jones \& Miles, 1978). Following the example of tennis, this technique consists of presenting a video of a serve to the returner where the duration of the sequence that they are allowed to watch varies, before occluding it. Studies have consistently found that expert athletes are able to predict, with a higher success rate than inexperienced players, the future location of the ball when the sequence is occluded in the moments prior to hitting it (e.g., Farrow et al., 2005).

This predictive capacity has been associated with the ability to begin their response sooner, so that tennis players appear to have all the time in the world (Bartlett, 1947). However, classical cognitive studies consider anticipation to be a perceptual-cognitive prediction ability that is, to a certain extent, disconnected from the habitual movement of athletes. It is possible that the results obtained in those studies whose experimental designs have lacked the necessary representativity are detached from reality (e.g., Travassos et al., 2013). In fact, it has been suggested that athletes in fast interceptive situations would process visual information through different neural streams depending on whether they are asked to perceive and predict (ventral stream), or instead they are required to perform a habitual action (dorsal stream; Van der Kamp et al., 2008; see also Goodale \& Milner, 1992).

In other words, the fact that expert athletes could predict with some success the direction of the ball in laboratory conditions does not necessarily mean that they have begun their return gesture sooner, anticipating one of the two sides in a real situation. As Bartlett himself points out, the question of expert athletes seeming to have all the time in the world refers to the timing of their actions (Bartlett, 1947, p. 836). In this sense, instead of assessing anticipation as a predictive capacity disconnected from movement, ecological and dynamical theoretical approaches consider the spatio-temporal structure of the task and the athlete's action capability (e.g., Araújo, Davids, \& Hristovski, 2006).

With regard to spatio-temporal pressure, the opponent's distance and the speed at which the ball arrives mark the time available to act, while space is associated with the dimensions of the playing field that the athlete must cover. For example, Triolet et al. (2013) observed in situ that tennis players began the action of hitting the ball during rallies according to the spatio-temporal pressure of the game situation. During groundstrokes, players began to move sideways about $220 \mathrm{~ms}$ 
after their opponents hit the ball, while during volleys that occur close to the net they do so in inferior times, sometimes even before their opponents hit the ball.

Regarding anticipation, in addition to the temporal pressure, the action capability of the athlete (e.g., speed, size, etc.) with which they can move within these spatio-temporal margins is also taken into account (Fajen, Riley, \& Turvey, 2009). This raises the following question: would the agility of an athlete influence the temporalization of their action? Dicks, Davids, and Button (2010c) explored this question in the real task of the football penalty, finding that the less agile goalkeepers started their saving actions sooner (between 150 and $250 \mathrm{~ms}$ before the athlete hit the ball), in contrast to the faster goalkeepers who waited more before moving (between 50 and $100 \mathrm{~ms}$ before the hit) towards one of the two sides.

In short, what expert athletes really do is - rather than anticipate or react adapt, adjust and calibrate their action. Regardless of the neuropsychological approach adopted to explain the phenomenon of compensation for neuronal delays (see review by Maus, Khurana, \& Nijhawan, 2010), what seems to be beyond doubt is the ability of the human system to carry out very precise temporalizations of limbs in interceptive anticipation quick actions (reaching the object at the right time in that exact place). Thus, to calibrate means to temporize actions according to the action capabilities of action and the spatio-temporal constraints of the task (Fajen et al., 2009; Jacobs \& Michaels, 2007).

Bearing this in mind, there are many possibilities within the temporal limits of action. For example, a tennis player can start their return movement sooner and move more slowly or start it later and act faster. It seems that expert athletes, rather than starting their response sooner, wait as long as they possibly can before replying (see also Oudejans, Michaels, \& Bakker, 1997). So why wait so long if starting sooner would allow more time for the displacement?

\section{Relationship between anticipation, information and performance}

As indicated in the previous section, the tasks of interception under spatial and temporal pressure imply a very particular dynamic of information variables. Biomechanical studies carried out indicate that available optical variables are more reliable (they relate better to the direction and speed of the object) the closer the opponent is to the moment of contact with the ball (e.g., Diaz et al., 2012). For example, the goalkeeper may start their lateral movement much sooner in order to ensure that they reach all areas of the goal, but at the expense of guiding their behaviour on less reliable (less useful) and potentially more misleading information (e.g., Lopes, Jacobs, Travieso, \& Araújo, 2014). Similarly, waiting for contact and the first moments of the ball direction would allow the goalkeeper to move in the direction of the ball, but probably with insufficient time to intercept it (Dicks et al., 2010c). In this sense, Dicks, Button, and Davids (2010a) found in their study that the faster goalkeepers (those who waited longer before throwing themselves) chose the correct side more times and were less susceptible to deception than slower goalkeepers (those who started their stoppage movements sooner). According to the authors, this is because waiting longer 
allowed goalkeepers to exploit information closer to the impact, which could more reliably guide their actions. In the same line, in the aforementioned study by Triolet et al. (2013), tennis players in situations of high temporal pressure moved towards the same side as that on which the stroke was finally directed approximately $70 \%$ of the time, since the need for anticipation forced them to guide their actions upon informational variables that were presumably less reliable. Conversely, when they returned the balls from groundstrokes (low temporal pressure), they constantly matched the ball's direction since they would begin to move after seeing the ball hit (above $200 \mathrm{~ms}$ after contact).

That is, athletes adjust their intercepting actions not only according to spatiotemporal constraints and to their own action capabilities, but also to the evolution over time of the specificity of the available information variables. In fact, the concept of calibration itself implies guiding behaviour based on available informational variables. In other words, to calibrate means to adapt actions according to the (a) spatio-temporal constraints of the task, (b) current action capabilities of the athlete and (c) usefulness of the informational sources available (Fajen et al., 2009; Jacobs \& Michaels, 2007).

It seems, therefore, that the temporalization of intercepting actions follows a definite, and more importantly, interdependent structure. That is, the success of the task (e.g., the goalkeeper blocking the penalty or the tennis player returning the ball) occurs with a balance between the three interrelated concepts. If one of these parameters is modified, it has an irremediable effect on the other two, or, in other words, each element modulates according to the other.

\section{Future research and conclusions}

The following question arises from the theoretical framework set out in the previous paragraphs: are there approximate time margins to initiate an action that can maximize success? The ideal temporalization of actions is variable since it depends on several factors, such as athletes' individual differences (agility to move), the evolution of the information available at each moment or the spatiotemporal pressure of each situation (distance, speed, space to cover). Nevertheless, certain conclusions can be drawn about those more or less stable tasks as there is abundant literature exploring them. Following the previous example, the best returners move laterally $160 \mathrm{~ms}$ after hitting the ball (Avilés, Ruiz, Sanz, \& Navia, 2014), and the most successful goalkeepers move laterally within the time range of approximately 100-200 ms before the hit (Dicks et al., 2010a, 2010c).

However, a growing number of studies (e.g., Navia et al., 2013) suggest that the balance in interceptive actions depends on each particular case. For example, individual differences should be considered when exploiting the optimal optical variables, or what has been called education of attention (Jacobs \& Michaels, 2007). The fact that certain variables emerge in the environment and/or that the variables already present increase in specificity does not necessarily mean that all athletes exploit them in the same way (Withagen \& Chemero, 2009). One goalkeeper might focus on the 
penalty taker's look (unreliable) just before starting the saving action to decide which side to move towards, while another goalkeeper might focus on the angle of the supporting leg (much more reliable; Ibánez-Gijón, Travieso \& Jacobs, 2011). Therefore, waiting more does not give any advantage to the former goalkeeper as the kicker's look does not provide extra information with respect to other information coming from the earlier moments during the run-up (e.g., angle of approach).

In addition, differences between expert athletes probably extend to the interaction between the exploitation of these optical variables and other contextual variables, such as the remaining time on the scoreboard, the opponent's position on the field or the adversary's individual preferences (Cañal-Bruland \& Mann, 2015). Along these lines, Navia et al. (2013) found that goalkeepers modified the temporalization of their saves, visual patterns and penalty performance when they were informed of the likelihood that the taker would aim towards a particular side of the goal. In addition, they found that the interaction between perceptual information (visual patterns) and situational information (kicking side probabilities) was different between some goalkeepers and others.

Additionally, the embodied approach's perception in sport (Avilés, Ruiz, Navia, Rioja, \& Sanz, 2014) suggests that there are differentiated perceptions (i.e., sizes, distances and even speeds) according to the competence and physical fitness of each athlete or the perceived difficulty (Witt, Linkenauger, \& Wickens, 2016). For example, Gray suggests that the perception of the speed of a football penalty shot can be conditioned by the goalkeeper's own ability to move sideways (i.e., their speed) in their attempt to save it (Gray, 2014, p. 77).

In short, although there are temporary margins in which the optimum temporalization of interception actions could be located, the balance depends on each athlete. Thus, coaches' training should be directed to finding the exact point of performance of each of their athletes. Therefore, in order to maximize athletes' success, an optimum balance between the previously mentioned factors should be sought specifically for each player. As Navia and Ruiz (2014) point out, a general piece of advice that seems to emerge and which is easily applicable is that athletes should stay in shape so that they are able to move as fast as possible, which will allow them to wait a little longer and thus be receptive to potentially more reliable information. A second, more individualized piece of advice would be to educate athletes to be more aware of reliable information (Ibánez-Gijón et al., 2011). Finally, they would ideally learn how to calibrate their capabilities according to the demands of the situation and the information available, a challenge for coaches. 


\section{Un enfoque actual de la anticipación en el deporte}

La anticipación de los deportistas ante tareas donde deben interceptar o devolver pelotas que vienen a gran velocidad ha sido uno de los temas más relevantes dentro de los estudios de percepción-acción en las últimas décadas (e.g., Howarth, Walsh, \& Abernethy, 1984). La propia estructura de ciertas tareas como el resto del servicio de tenis o el penalti de fútbol obligan al deportista a actuar en la frontera de lo imposible, llegando a realizar acciones perfectamente temporalizadas con gran destreza motriz (competencia).

Qué procesos perceptivo-motrices subyacen a ese rendimiento experto, es la pregunta que ha motivado a los investigadores adentrarse en el análisis de la percepción visual y la temporalización de los movimientos. Esta corriente de estudio confluye en el término actualmente muy utilizado de la anticipación, también conocida como anticipación visual (Williams, Davids, \& Williams, 1999, p. 97). A pesar de su amplia difusión y uso en la literatura, el concepto de anticipación ha venido generando cierta controversia (e.g., Van der Kamp, Rivas, Van Doorn, \& Savelsbergh, 2008). Esta controversia tiene su origen en la raíz teórica del término, pasando por los diseños metodológicos de los estudios, así como las diferentes fórmulas y aspectos relacionados con la misma.

\section{Conceptualización de la anticipación}

La terminología relacionada con la forma de responder es fundamental para los especialistas del movimiento humano (comportamiento motor) ya que la utilización adecuada de los diferentes conceptos y términos, tiene una incidencia directa en el método empleado y en la validez de las diferentes medidas tempo-rales. Como destacaba Williams James en su obra clásica Principios de Psicología, desde el siglo XIX el Tiempo de Reacción (TR) y la cronometría mental, ha sido uno de los paradigmas experimentales más utilizados en los laboratorios para medir el tiempo que tarda en reaccionar el ser humano a un determinado estímulo y poder explorar, de este modo, el tiempo de los procesos mentales. Por ejemplo, en el estudio clásico de Hick (1952) se especifica como estímulo principal el momento en el que el filamento de la bombilla se vuelve incandescente. La respuesta de los participantes se registraba cuando pulsaban una tecla de morse situada frente a ellos. De esta forma, se midió el TR como el tiempo transcurrido entre el encendido de la luz y la pulsación de la tecla de morse. Estudios neuropsicológicos en torno a las demoras neuronales (e.g., flash-lag effect; Nijhawan, 2002) sugieren que este TR es el mínimo requerido por el sistema nervioso para procesar esa información (i.e, procesamiento visual, integración multisensorial, codificación temporal de la 
información) y realizar una acción simple (producción de la orden motriz). A pesar de que en algunos estudios recientes con deportistas se ha seguido utilizando el paradigma del TR la tendencia apunta a que ese paradigma no resulta un indicador fiable del rendimiento experto ya que no representa lo que sucede realmente en el contexto deportivo (e.g., Martínez de Quel, Bennett, Lopez-Adan, Zapico, \& Saucedo-Morales, 2015).

Las acciones deportivas son realizadas en el contexto de juego y requieren de movimientos o respuestas complejas que nada tienen que ver con una acción simple como liberar un botón, levantar una mano o pulsar una tecla. La utilización de términos como tiempo de respuesta (e.g., Avilés, Ruiz, Sanz, \& Navia, 2014; Triolet, Benguigui, Le Runigo, \& Williams, 2013), tiempo de inicio del movimiento, del cuerpo entero, de un segmento o del implemento (e.g., Gillet, Leroy, Thouvarecq, Mégrot, \& Stein, 2010) o lapso visomotor (LVM: del inglés visuomotor delay; e.g., Bootsma, Fernandez, Morice, \& Montagne, 2010; Le Runigo, Benguigui, \& Bardy, 2010) parecen reflejar de forma más pertinente las adaptaciones, los ajustes, las correcciones o las respuestas que realizan los deportistas.

Los especialistas apuntan hacia una distinción entre el TR y el LVM en algunos aspectos (e.g., Carlton, 1992). El TR se relaciona con la teoría cognitiva de procesamiento de la información, asociándose a tareas discretas y promediando aproximadamente entre 180 y 200 ms (Vickers, 2007, p. 48). En cambio, el LVM se asocia a un acoplamiento directo y rápido entre información y movimiento. Los valores del LVM pueden ser muy cortos (inferiores a $100 \mathrm{~ms}$ ) cuando la información se utiliza de un modo continuo en ajustes o adaptaciones rápidas durante un movimiento de larga duración (Bootsma et al., 2010, p. 1059; Van der Kamp et al., 2008, p. 124). En cambio, también se pueden obtener valores de 200 e incluso $300 \mathrm{~ms}$ cuando la información es utilizada de un modo discreto en el inicio del movimiento o en el caso de una gran corrección (Benguigui, Baurès, \& Le Runigo, 2008, p. 200; Le Runigo et al., 2010, p. 328). Esta gran variación temporal es mencionada por algunos autores quienes, por un lado, utilizan el término intervalo visomotor que tiene una connotación más neutra o flexible en cuanto a la duración del periodo de tiempo entre estímulo y movimiento, y por otro, critican la visión tradicional en investigación que interpreta frecuentemente las latencias como un tiempo mínimo e invariable (Caljouw, Van der Kamp, \& Savelsbergh, 2004; Michaels, Zeinstra, \& Oudejans, 2001).

La cuestión de fondo que refleja la disparidad en terminología y en valores encontrados es la escasa similitud entre el laboratorio y las acciones deportivas. Incluso las investigaciones relacionadas con el LVM (a priori más representativo) se llevaron a cabo en condiciones controladas (e.g, Benguigui et al., 2008). Las acciones deportivas no son tan fácilmente registrables, diferenciándose de lo que sucede en el laboratorio en al menos tres aspectos: (a) la relación entre estímulo y respuesta, (b) la presentación del estímulo y (c) el registro de la respuesta.

En relación al primer apartado, aunque el deportista que lanza tiene la iniciativa, no deja de existir una mutua temporalización de las acciones, una dependencia en un transcurso relativamente largo de la acción entre los dos oponentes: el que lanza y el que recibe (Avilés, Benguigui, Beaudoin, \& Godard, 2002). Por 
ejemplo, en el caso del penalti de fútbol, el portero de fútbol se fija en el tirador para intentar atajar el balón desde el momento que posa el balón en el punto de penalti (Furley, Dicks, \& Memmert, 2012), acentuándose cuando inicia su carrera de aproximación hacia el balón (Dicks, Button, \& Davids, 2010b; Navia, Van der Kamp, \& Ruiz, 2013). Por su lado, el tirador también se fija en el portero, llegando incluso a modular la dirección de su tiro en función de las acciones del portero (Noël, Furley, Van der Kamp, Dicks, \& Memmert, 2014).

Esta dependencia mutua junto con la relativa larga duración del evento (e.g., la carrera de aproximación en el penalti de fútbol dura entre 1,000 y 2,000 ms; Dicks et al., 2010b; Navia et al., 2013), hace que no resulte fácil determinar el momento en el que aparecen los estímulos ni la respuesta. En cuanto al estímulo, existe un consenso en los estudios de anticipación interceptiva de tomar como referencia para el análisis temporal de la secuencia el momento de contacto entre el lanzador y el móvil (Howarth et al., 1984). No porque en ese momento aparezca el estímulo en sí, sino porque es cuando se produce una alteración crucial en la información óptica disponible. Los estudios biomecánicos confirman que las variables ópticas concernientes a los movimientos previos de los lanzadores puede que se relacionen en cierto grado con la dirección final del móvil, pero no es hasta el golpeo y los primeros momentos de vuelo de la bola cuando se correlacionan totalmente con la dirección y velocidad de la bola (e.g., Diaz, Fajen, \& Phillips, 2012). Dicho de otra forma, el deportista que recibe no percibe con certeza la dirección y velocidad hasta el momento en torno al golpeo y primeros momentos de vuelo de la bola, por lo que parece razonable considerar ese instante como punto 0 en el análisis cronométrico. Por ejemplo, en el caso del penalti de fútbol se corresponde con el contacto entre el pie del tirador y el balón (e.g., Savelsbergh, Williams, Van der Kamp, \& Ward, 2002) o en el caso del tenis, con el contacto entre la raqueta del servidor y la pelota (Day, 1980). Sin embargo, que se emplee ese momento como referencia no significa que el estímulo aparezca en ese instante, ya que, como se comentaba, existe una disponibilidad de información más o menos fiable en momentos previos.

En relación a la respuesta, existe una disparidad en los criterios a la hora de registrar el inicio del movimiento de interceptación. Algunos estudios consideran que el deportista que recibe, inicia su acción cuando se desplaza lateralmente hacia uno de los lados (e.g., Farrow, Abernethy, \& Jackson, 2005). Otros, consideran los movimientos regulatorios previos a ese desplazamiento lateral (e.g., Avilés, Ruiz, Sanz, \& Navia, 2014). Y para mayor confusión, otros estudios emplean la medición de diversas variables (e.g., movimientos del centro de gravedad, inicio del desplazamiento lateral de la raqueta, etc.) como registro temporal de la acción de respuesta (e.g., Gillet et al., 2010).

Por último, si se toma en cuenta los tres aspectos mencionados, la investigación considera que el deportista anticipa si ese registro de la respuesta (generalmente el desplazamiento lateral) se produce antes del golpeo de la bola, y por el contrario reacciona si se mueve después del contacto (e.g., Williams et al., 1999). En cambio, como se ha podido ver anteriormente, existe una latencia entre 
el estímulo y respuesta (TR alrededor de los $180 \mathrm{~ms}$ o LVM por encima de $100 \mathrm{~ms}$ ), por lo que otra interpretación supondría considerar anticipación cuando el deportista se mueve por debajo de una de esas fronteras temporales. Por ejemplo, Triolet et al. (2013, p. 825) consideran que si el tenista comienza su acción antes de los $160 \mathrm{~ms}$ posteriores al golpeo está anticipando, y que si lo hace después, está reaccionando.

En definitiva, vemos cómo tanto el momento de la acción de respuesta como la propia cuantificación de la anticipación podrían reformularse desde un punto de vista teórico y metodológico al considerar si tiene sentido establecer una barrera entre anticipación y reacción cuando se trata de un proceso continuo de temporalización y regulación del movimiento de los deportistas.

\section{Anticipar y calibrar la respuesta}

El concepto clásico de anticipación visual se refiere a la habilidad que tienen los deportistas expertos para detectar pistas (señales) corporales de los contrincantes (oponentes) de forma temprana y predecir la dirección del envío de la bola (Poulton, 1957). Siguiendo esta corriente cognitiva, otros autores han definido la anticipación como la capacidad de predecir correctamente situaciones antes de que ocurran (e.g., Tenenbaum, Sar-El, \& Bar-Eli, 2000, p. 119). Es decir, desde ese punto de vista, anticipar significaría predecir correctamente (e.g., respuesta escrita) y no necesariamente moverse (cf. Van der Kamp et al., 2008). Esta capacidad predictiva de la anticipación se deriva de otras habilidades cognitivas específicas como reconocimiento temprano de pistas, reconocimiento de patrones, una búsqueda visual refinada o el empleo de probabilidades situacionales (Williams \& Ford, 2008).

Con el objetivo de registrar el nivel de anticipación espacial de los deportistas, se ha utilizado de forma muy prolífica la técnica de oclusión temporal (Jones \& Miles, 1978). Siguiendo el ejemplo del tenis, esta técnica consiste en presentar al restador un vídeo de un servicio de tal forma que varíe la duración de la secuencia que se le permite ver antes de ocluirlo. Los estudios han encontrado de forma consistente que los deportistas expertos son capaces de predecir, con un mayor índice de éxito que los novatos, la futura localización de la pelota cuando se les ocluía la secuencia en momentos previos al golpeo (e.g., Farrow et al., 2005).

Esta capacidad predictiva se ha asociado a la capacidad de comenzar antes su respuesta, de tal forma que los tenistas parecen disponer de todo el tiempo del mundo (Bartlett, 1947). Sin embargo, los estudios cognitivos clásicos consideran la anticipación como una capacidad perceptivo-cognitiva de predicción desconectada, en cierto modo, del movimiento habitual de los deportistas. Posiblemente, los resultados obtenidos en aquellos estudios cuyos diseños experimentales han carecido de la necesaria representatividad estén alejados de la realidad (e.g., Travassos, Araújo, Davids, O’Hara, Leitão, \& Cortinhas, 2013). De hecho, se ha sugerido que los deportistas en situaciones rápidas de interceptación procesarían la información visual por diferentes vías neuronales en función de si lo solicitado es percibir y predecir (vía ventral), o por el contrario se requiere una 
actuación habitual (vía dorsal; Van der Kamp et al., 2008; ver también Goodale \& Milner, 1992).

Dicho de otra forma, el hecho de que los deportistas expertos pudieran predecir con cierto éxito la dirección de la pelota en condiciones de laboratorio no significa necesariamente que comiencen antes su gesto de resto anticipando hacia uno de los dos lados en una situación real. Como el propio Bartlett apunta, la cuestión de que los deportistas expertos parezca que tengan todo el tiempo del mundo hace referencia más bien a una cuestión de temporalización de sus acciones (Bartlett, 1947, p. 836). En este sentido, corrientes teóricas de corte ecológico y dinámico, en lugar de valorar la anticipación como una capacidad de predicción desconectada del movimiento, toman en cuenta la estructura espaciotemporal de la tarea y la capacidad funcional del deportista (e.g, Araújo, Davids, \& Hristovski, 2006).

Con respecto a la presión espaciotemporal, la distancia del oponente y la velocidad a la que viene la bola marcan el tiempo disponible para actuar, mientras que el espacio se refiere a las dimensiones del terreno de juego que debe cubrir el deportista. Por ejemplo, Triolet et al. (2013) observaron in situ que los tenistas comenzaban su acción de golpeo durante los intercambios en función de la presión espacio-temporal de la situación de juego. Durante los golpes de fondo, los tenistas comenzaban a moverse lateralmente alrededor de $220 \mathrm{~ms}$ después del golpeo del adversario, mientras que durante las voleas cercanas a la red lo hacían en tiempos inferiores, en ocasiones antes incluso del golpeo del oponente.

En relación con la anticipación, además de la presión temporal también se toma en cuenta la capacidad funcional del deportista (e.g., rapidez, tamaño, etc.) con la que se puede mover dentro de esos márgenes espacio-temporales (Fajen, Riley, \& Turvey, 2009). Esto plantea la siguiente cuestión: ¿influirá la agilidad de un deportista a la hora de temporalizar su acción? Dicks, Davids y Button (2010c) se propusieron estudiar esta cuestión en la tarea real del penalti de fútbol, encontrando que los porteros menos ágiles comenzaban antes su movimiento de parada de los penaltis (entre 150 y $250 \mathrm{~ms}$ previos al golpeo), en contraste con los porteros más rápidos que esperaban más tiempo para tirarse (entre 50 y $100 \mathrm{~ms}$ previos al golpeo) hacia uno de los dos lados.

En definitiva, los deportistas expertos, más que anticipar o reaccionar, lo que realmente hacen es adaptar, ajustar, calibrar su acción. Independientemente de la aproximación neuropsicológica adoptada para para explicar el fenómeno de la compensación a las demoras neuronales (revisión en Maus, Khurana, \& Nijhawan, 2010), lo que parece estar fuera de duda es la capacidad del sistema humano para realizar temporalizaciones muy precisas de los miembros en acciones rápidas de anticipación interceptiva (alcanzar el objeto en el momento justo en ese lugar exacto). Calibrar por tanto significa temporalizar las acciones propias en función de las capacidades funcionales de acción y de los condicionantes espacio-temporales de la tarea (Fajen et al., 2009; Jacobs \& Michaels, 2007).

Teniendo esto en cuenta, dentro de los márgenes temporales de actuación caben muchas posibilidades. Por ejemplo, un tenista puede iniciar su movimiento de resto antes y moverse más lentamente o iniciarlo más tarde y actuar más rápidamente. 
Parece ser que los deportistas expertos, antes que iniciar de forma más temprana su respuesta, lo que hacen es esperar todo lo que pueden hasta responder (ver también Oudejans, Michaels, \& Bakker, 1997). Entonces, ¿por qué esperar tanto si comenzando antes permitiría ganar más tiempo para el desplazamiento?

\section{Relación entre anticipación, información y rendimiento}

Como se ha indicado en el apartado anterior, las tareas de interceptación bajo presión espacial y temporal conllevan una dinámica de las varia-bles informativas muy particular. Los estudios biomecánicos llevados a cabo indican que las variables ópticas disponibles son más fiables (se relacionan mejor con la dirección y velocidad del móvil) cuanto más se acerca el oponente al momento del contacto con la pelota (e.g., Díaz et al., 2012). Por ejemplo, el portero puede comenzar su desplazamiento lateral muy tempranamente para así asegurarse llegar a todas las zonas de la portería, pero lo haría a expensas de guiar su conducta sobre informaciones menos fiables (menos útiles) y potencialmente más engañosas (e.g., Lopes, Jacobs, Travieso, \& Araújo, 2014). Del mismo modo, esperar a ver el contacto y primeros momentos del vuelo del balón le permitiría sin duda moverse en la dirección del balón, pero probablemente con un margen temporal insuficiente como para llegar a interceptarlo (Dicks et al., 2010c). En este sentido Dicks, Button, y Davids (2010a) encontraron en su estudio que los porteros más rápidos (que esperaban más antes de tirarse) acertaron más veces el lado del disparo y fueron menos susceptibles al engaño que sus compañeros más lentos (que se iniciaban antes su movimiento de parada). Según estos autores, esto se debe a que al esperar más fueron capaces de explotar las informaciones más cercanas al impacto, y por lo tanto, más fiables para guiar sus acciones. En la misma línea, en el mencionado estudio de Triolet et al. (2013) los tenistas en situaciones de alta presión temporal se movían hacia el mismo lado al que finalmente se dirigía el golpe en torno a un $70 \%$ de las ocasiones, ya que la necesidad de anticipación les hacía guiar sus acciones sobre variables informativas presumiblemente menos fiables. En cambio, cuando devolvían las pelotas desde el fondo (baja presión temporal), acertaban constantemente la dirección de la bola ya que comenzaban a moverse tras ver el golpeo (por encima de los $200 \mathrm{~ms}$ tras el contacto).

Es decir, los deportistas ajustan sus acciones de interceptación no solamente en función de los condicionantes espacio-temporales y de sus propias capacidades funcionales, sino de la evolución en el tiempo de la especificidad de las variables informativas disponibles. De hecho, el propio concepto de calibración implica guiar la conducta en función de variables informativas disponibles. Es decir, calibrar significa adaptar las acciones en función de (a) los condicionantes espacio-temporales de la tarea, (b) las capacidades funcionales actuales del atleta, y (c) la utilidad de las fuentes informacionales disponibles (Fajen et al., 2009; Jacobs \& Michaels, 2007). 
Parece ser, por tanto, que la temporalización de las acciones de interceptación sigue una estructura definida y lo más importante, interdependiente. Es decir, el éxito de la tarea (e.g., que el portero alcance el penalti o que el tenista devuelva la pelota) se sitúa en el equilibrio entre los tres conceptos interrelacionados. Si se modifica uno de estos parámetros, tiene un efecto irremediable sobre los otros dos o, dicho de otra forma, en función de cada uno de esos elementos, se modulan los restantes.

\section{Prospectivas de investigación y conclusiones}

Tomando como referencia el marco teórico expuesto en los párrafos anteriores, la siguiente cuestión que se plantea es: ¿existen márgenes temporales aproximados para iniciar la acción que maximicen las opciones de éxito? La temporalización ideal de las acciones es muy variable puesto que depende de varios factores como las diferencias individuales de los deportistas (agilidad para moverse), evolución de la información disponible en cada instante, o presión espacio-temporal de cada situación (distancia, velocidad, espacio para cubrir). No obstante, se puede realizar ciertas aproximaciones en aquellas tareas más o menos estables en las que existe abundante literatura. Siguiendo con el ejemplo anterior, los mejores restadores se mueven lateralmente a partir de los $160 \mathrm{~ms}$ posteriores al golpeo (Avilés, Ruiz, Sanz, \& Navia, 2014), y los porteros con mayor índice de paradas se mueven lateralmente en un margen de unos 100 a 200 ms previos al golpeo (Dicks et al., 2010a, 2010c).

Sin embargo, cada vez más estudios (e.g., Navia et al., 2013) apuntan a que el equilibrio en las acciones de interceptación depende de cada caso en particular. Por ejemplo, se debería considerar las diferencias individuales a la hora de explotar las variables ópticas óptimas, o lo que se ha denominado educación de la atención (Jacobs \& Michaels, 2007). El hecho de que vayan emergiendo ciertas variables en el entorno y/o las variables presentes aumenten de especificidad, no significa necesariamente que todos los deportistas las exploten de igual forma (Withagen \& Chemero, 2009). Un portero puede fijarse justo antes de tirarse en la mirada del tirador para decidir el lado (pista poco fiable) mientras que otro puede fijarse en el ángulo de la pierna de apoyo (mucho más fiable; Ibánez-Gijón, Travieso, \& Jacobs, 2011). Por tanto, el hecho de esperar más no le supone ninguna ventaja al primero ya que esa pista no le aporta información extra con respecto a otra información que pueda aparecer previamente durante la carrera de aproximación del tirador (e.g., ángulo de aproximación).

Además, las diferencias entre deportistas expertos probablemente se extienden a la interacción entre la explotación de estas variables ópticas con otras variables contextuales, como por ejemplo, la ventaja en el marcador con respecto al tiempo restante, la posición del oponente en la pista, o las preferencias individuales del adversario (Cañal-Bruland \& Mann, 2015). En este sentido, Navia et al. (2013) encontraron que los porteros modificaban su temporalización de la parada, sus patrones visuales y su rendimiento en los penaltis cuando se les informaba sobre la probabilidad de que el tirador lanzase hacia un lado concreto de la portería. 
Además, encontraron que la interacción entre la información perceptiva (patrones visuales) y la información situacional (probabilidades del lado de disparo) era diferente entre unos porteros y otros.

Además, el enfoque corporizado (embodimient) de la percepción en el deporte (Avilés, Ruiz, Navia, Rioja, \& Sanz, 2014), alude a que realmente existen percepciones diferenciadas (i.e., tamaños, distancias e incluso velocidades) en función de la competencia, estado físico o dificultad percibida de cada deportista (Witt, Linkenauger, \& Wickens, 2016). Por ejemplo, Gray sugiere que la percepción de la velocidad de disparo de penalti de fútbol puede verse condicionada por la propia capacidad del portero para moverse lateralmente (i.e., rapidez) en su intento de pararlo (Gray, 2014, p. 77).

En definitiva, a pesar de que existen unos márgenes temporales en los que se podría situar la temporalización óptima de las acciones de interceptación, el equilibrio es individual a cada deportista. El trabajo de los entrenadores entonces debería encaminarse a encontrar el punto exacto de rendimiento de cada uno de sus deportistas. Para maximizar las opciones de éxito de los deportistas, por tanto, se debería buscar el equilibrio óptimo de los factores anteriormente mencionados de forma específica para cada jugador. Como apuntan Navia y Ruiz (2014), un consejo general que parece desprenderse, y además resulta fácilmente aplicable, es que los deportistas se mantengan en forma para que sean capaces de moverse lo más rápido posible, lo cual les permitirá esperar un poquito más y así estar expuestos a informaciones potencialmente más fiables. Un segundo consejo más individual sería educar la atención de los deportistas hacia aquellas informaciones que resulten fiables (Ibánez-Gijón et al., 2011). Por último, lo ideal sería que aprendieran a calibrar sus capacidades con las demandas de la situación y la información disponible, un reto para los entrenadores.

\section{Disclosure statement}

No potential conflict of interest was reported by the authors / Los autores no han referido ningún potencial conflicto de interés en relación con este artículo.

\section{ORCID}

José-Antonio Navia (D) http://orcid.org/0000-0003-1218-5033

Carlos Avilés (D) http://orcid.org/0000-0001-9540-1808

Sergio López (1) http://orcid.org/0000-0003-3109-1542

Luis-Miguel Ruiz (D) http://orcid.org/0000-0002-9678-5986

\section{References / Referencias}

Araújo, D., Davids, K., \& Hristovski, R. (2006). The ecological dynamics of decision making in sport. Psychology of Sport and Exercise, 7, 653-676. doi:10.1016/j. psychsport.2006.07.002

Avilés, C., Benguigui, N., Beaudoin, E., \& Godard, F. (2002). Developing early perception and getting ready for action on the return of serve. ITF Coaching \& Sport Science Review, 28, 6-8. 
Avilés, C., Ruiz, L. M., Navia, J. A., Rioja, N., \& Sanz, D. (2014). La pericia perceptivomotriz y cognición en el deporte: Del enfoque ecológico y dinámico a la enacción. Anales de Psicología, 30, 725-737. doi:10.6018/analesps.30.2.158611

Avilés, C., Ruiz, L. M., Sanz, D., \& Navia, J. A. (2014). Adaptive and reactive skills involved in the return of serve in tennis. ITF Coaching \& Sport Science Review, 22, 6-8.

Bartlett, F. (1947, June 14). The measurement of human skill. British Journal Medical, 835-838, 877-880. doi:10.1136/bmj.1.4511.877

Benguigui, N., Baurès, R., \& Le Runigo, C. (2008). Visuomotor delay in interceptive actions. Behavioral \& Brain Sciences, 31, 200-201. doi:10.1017/s0140525x0800383x

Bootsma, R. J., Fernandez, L., Morice, A. H., \& Montagne, G. (2010). Top-level players' visual control of interceptive actions: Bootsma and Van Wieringen (1990) 20 years later. Journal of Experimental Psychology: Human Perception and Performance, 36, 1056-1063. doi:10.1037/a0019327

Caljouw, S. R., Van der Kamp, J., \& Savelsbergh, G. J. P. (2004). Timing of goal-directed hitting: Impact requirements change the information-Movement coupling. Experimental Brain Research, 155, 135-144. doi:10.1007/s00221-003-1705-0

Carlton, L. G. (1992). Visual processing time and the control of movement. In L. Proteau \& D. Elliott (Eds.), Vision and motor control (pp. 3-31). Amsterdam: Elsevier Science Publishers.

Cañal-Bruland, R., \& Mann, D. L. (2015). Time to broaden the scope of research on anticipatory behavior: A case for the role of probabilistic information. Frontiers in Psychology, 6, 1518. doi:10.3389/fpsyg.2015.01518

Day, L. J. (1980). Anticipation in junior tennis players. In J. Groppel \& R. Sears (Eds.). Proceedings of International symposium on effective teaching of raquet sports (pp. 107-116). Champaign, IL: University of Illinois.

Diaz, G. J., Fajen, B. R., \& Phillips, F. (2012). Anticipation from biological motion: The goalkeeper problem. Journal of Experimental Psychology: Human Perception and Performance, 38, 848-864. doi:10.1037/a0026962

Dicks, M., Button, C., \& Davids, K. (2010a). Availability of advance visual information constrains association-football goalkeeping performance during penalty kicks. Perception, 39, 1111-1124. doi:10.1068/p6442

Dicks, M., Button, C., \& Davids, K. (2010b). Examination of gaze behaviors under in situ and video simulation task constraints reveals differences in information pickup for perception and action. Attention, Perception, \& Psychophysics, 72, 706-720. doi:10.3758/APP.72.3.706

Dicks, M., Davids, K., \& Button, C. (2010c). Individual differences in the visual control of intercepting a penalty kick in association football. Human Movement Science, 29, 401-411. doi:10.1016/j.humov.2010.02.008

Fajen, B., Riley, M., \& Turvey, M. (2009). Information, affordances and the control of acton in sport. International Journal of Sport Psychology, 40, 79-107.

Farrow, D., Abernethy, B., \& Jackson, R. (2005). Probing expert anticipation with the temporal occlusion paradigm: Experimental investigations of some methodological issues. Motor Control, 9, 330-349. doi:10.1123/mcj.9.3.330

Furley, P., Dicks, M., \& Memmert, D. (2012). Nonverbal behavior in soccer: The influence of dominant and submissive body language on the impression formation and expectancy of success of soccer players. Journal of Sport \& Exercise Psychology, 34, 61-82. doi:10.1123/jsep.34.1.61

Gillet, E., Leroy, D., Thouvarecq, R., Mégrot, F., \& Stein, J.-F. (2010). Movementproduction strategy in tennis: A case study. Journal of Strength and Conditioning Research, 24, 1942-1947. doi:10.1519/JSC.0b013e3181dc4622

Goodale, M., \& Milner, D. (1992). Separate visual pathways for perception and action. Trends in Neurosciences, 15, 20-25. doi:10.1016/0166-2236(92)90344-8 
Gray, R. (2014). Embodied perception in sport. International Review of Sport and Exercise Psychology, 7, 72-86. doi:10.1080/1750984X.2013.871572

Hick, W. E. (1952). On the rate of gain of information. Quarterly Journal of Experimental Psychology, 4, 11-26. doi:10.1080/17470215208416600

Howarth, C., Walsh, W. D., \& Abernethy, B. (1984). A field examination of anticipation in squash: Some preliminary data. Australian Journal of Science \& Medicine in Sport, $16,6-10$.

Ibánez-Gijón, J., Travieso, D., \& Jacobs, D. (2011). El enfoque neogibsoniano como marco conceptual y metodológico para el diseño de programas de entrenamiento deportivo. Revista de Psicología del Deporte, 20, 677-688.

Jacobs, D. M., \& Michaels, C. F. (2007). Direct Learning. Ecological Psychology, 19, 321-349. doi:10.1080/10407410701432337

Jones, C. M., \& Miles, T. R. (1978). Use of advance cues in predicting the flight of a lawn tennis ball. Journal of Human Movement Studies, 4, 231-235.

Le Runigo, C., Benguigui, N., \& Bardy, B. G. (2010). Visuo-motor delay, information-movement coupling, and expertise in ball sports. Journal of Sports Sciences, 28, 327-337. doi:10.1080/02640410903502782

Lopes, J., Jacobs, D. M., Travieso, D., \& Araújo, D. (2014). Predicting the lateral direction of deceptive and non-deceptive penalty kicks in football from the kinematics of the kicker. Human Movement Science, 36, 199-216. doi:10.1016/j.humov.2014.04.004

Martinez de Quel, O., Bennett, S. J., Lopez-Adan, E., Zapico, A. G., \& Saucedo-Morales, F. (2015). Choice reaction time is not related to competition success in karate combat. European Journal of Human Movement, 35, 41-50.

Maus, G., Khurana, B., \& Nijhawan, R. (2010). History and theory of flash-lag: Past, present, and future. In R. Nijhawan \& B. Khurana (Eds.), Space and time in perception and action (pp. 477-503). Cambridge: Cambridge University Press.

Michaels, C. F., Zeinstra, E. B., \& Oudejans, R. (2001). Information and action in punching a falling ball. The Quarterly Journal of Experimental Psychology Section $A, 54 A, 69-93$. doi:10.1080/02724980042000039

Navia, J. A., \& Ruiz, L. M. (2014). Análisis de la complejidad perceptivo-motriz y psicológica del penalti en el fútbol [Analysis of the perceptual-motor and psychological complexity of the soccer penalty kick]. RICYDE. Revista Internacional de Ciencias del Deporte, 10, 264-280. doi:10.5232/ricyde2014.03706

Navia, J. A., Van der Kamp, J., \& Ruiz, L. M. (2013). On the Use of Situational and Body Information in Goalkeeper Actions during a Soccer Penalty Kick. International Journal of Sport Psychology, 44, 234-251. doi:10.7352/IJSP2013.43.000

Nijhawan, R. (2002). Neural delays, visual motion and the flash-lag effect. Trends in Cognitive Sciences, 6, 387-393. doi:10.1016/S1364-6613(02)01963-0

Noël, B., Furley, P., Van der Kamp, J., Dicks, M., \& Memmert, D. (2014). The development of a method for identifying penalty kick strategies in association football. Journal of Sports Sciences, 1-10. doi:10.1080/02640414.2014.926383

Oudejans, R. R. D., Michaels, C. F., \& Bakker, F. C. (1997). The effects of baseball experience on movement initiation in catching fly balls. Journal of Sports Sciences, 15, 587-595. doi:10.1080/026404197367029

Poulton, E. (1957). On prediction in skilled movements. Psychological Bulletin, 54, 467-478. doi:10.1037/h0045515

Savelsbergh, G., Williams, A. M., Van der Kamp, J., \& Ward, P. (2002). Visual search, anticipation and expertise in soccer goalkeepers. Journal of Sports Sciences, 20, 279-287. doi:10.1080/026404102317284826

Tenenbaum, G., Sar-El, T., \& Bar-Eli, M. (2000). Anticipation of ball location in low and high-skill performers: A developmental perspective. Psychology of Sport and Exercise, 1, 117-128. doi:10.1016/S1469-0292(00)00008-X 
Travassos, B., Araújo, D., Davids, K., O’Hara, K., Leitão, J., \& Cortinhas, A. (2013). Expertise effects on decision-making in sport are constrained by requisite response behaviours - A meta-analysis. Psychology of Sport and Exercise, 14, 211-219. doi:10.1016/j.psychsport.2012.11.002

Triolet, C., Benguigui, N., Le Runigo, C., \& Williams, A. M. (2013). Quantifying the nature of anticipation in professional tennis. Journal of Sports Sciences, 31, 820-830. doi:10.1080/02640414.2012.759658

Van der Kamp, J., Rivas, F., Van Doorn, H., \& Savelsbergh, G. (2008). Ventral and dorsal system contributions to visual anticipation in fast ball sports. International Journal of Sport Psychology, 39, 100-130.

Vickers, J. N. (2007). Perception, cognition and decision training. The quiet eye in action. Champaign: Human Kinetics.

Williams, A. M., Davids, K., \& Williams, J. G. (1999). Visual perception and action in sport. London: Spon Press.

Williams, A. M., \& Ford, P. (2008). Expertise and expert performance in sport. International Review of Sport \& Exercise Psychology, 1, 4-18. doi:10.1080/ 17509840701836867

Withagen, R., \& Chemero, A. (2009). Naturalizing Perception. Theory \& Psychology, 19, 363-389. doi:10.1177/0959354309104159

Witt, J. K., Linkenauger, S. A., \& Wickens, C. (2016). Action-specific effects in perception and their potential applications. Journal of Applied Research in Memory and Cognition, 5, 69-76. doi: https://doi.org/10.1016/j.jarmac.2015.07.008 